\title{
Correction to: Elevated plasma IL-6 and CRP levels are associated with adverse clinical outcomes and death in critically ill SARS-CoV-2 patients: infammatory response of SARS-CoV-2 patients
}

Jean-Rémi Lavillegrand ${ }^{1,2}$, Marc Garnier ${ }^{2,3}$, Agathe Spaeth ${ }^{4}$, Nathalie Mario ${ }^{4}$, Geofroy Hariri 1,2, Antoine Pilon ${ }^{4}$, Enora Berti ${ }^{2,5}$, Fabienne Fieux ${ }^{3}$, Sara Thietart ${ }^{1}$, Tomas Urbina ${ }^{1,2}$, Matthieu Turpin ${ }^{2,5}$, Lucie Darrivere ${ }^{3}$, Muriel Fartoukh ${ }^{2,5}$, Franck Verdonk ${ }^{3}$, Guillaume Dumas' ${ }^{1}$, Alain Tedgui ${ }^{6}$, Bertrand Guidet ${ }^{1,2}$, Eric Maury ${ }^{1,2}$, Yannick Chantran ${ }^{7}$, Guillaume Voiriot ${ }^{2,5}$ and Hafd Ait-Oufella ${ }^{1,2,6^{*}}$ (1)

Correction to: Ann Intensive Care 11:9 (2021) https://doi.org/10.1186/s13613-020-00798-x

After publication of the original article [1], an error was identified in Lucie Darrivere's name.

The incorrect name is: Lucie Darrivière.

The correct name i: Lucie Darrivere.

The original article has been corrected.

\section{Author details}

'Service de Médecine Intensive-Réanimation, Hôpital Saint-Antoine, Assistance Publique-Hôpitaux de Paris, 184 rue du faubourg Saint-Antoine, 75571 Paris cedex 12, France. ${ }^{2}$ Sorbonne Université, Paris, France. ${ }^{3}$ Service D'Anesthésie-Réanimation, Hôpital Saint-Antoine, Assistance PubliqueHôpitaux de Paris, Paris, France. ${ }^{4}$ Département de Biochimie, Hormonologie et Suivi Thérapeutique, Hôpital Saint-Antoine, Assistance Publique-Hôpitaux de Paris, Paris, France. ${ }^{5}$ Service de Médecine Intensive-Réanimation, Hôpital Tenon, Assistance Publique-Hôpitaux de Paris, Paris, France. ${ }^{6}$ Inserm U970, Cardiovascular Research Center, Université de Paris, Paris, France. ${ }^{7}$ Départe- Ment D'Immunologie Biologique, Hôpital Saint-Antoine, Assistance PubliqueHôpitaux de Paris, Paris, France.
Published online: 09 June 2021

\section{Reference}

1. Lavillegrand J, Garnier M, Spaeth A, Mario N, Hariri G, Pilon A, Berti E, Fieux F, Thietart S, Urbina T, Turpin M, Darrivere L, Fartoukh M, Verdonk F, Dumas G, Tedgui A, Guidet B, Maury E, Chantran Y, Voiriot G, Ait-Oufella H. Elevated plasma IL-6 and CRP levels are associated with adverse clinical outcomes and death in critically ill SARS-CoV-2 patients: infammatory response of SARS-CoV-2 patients. Ann Intensive Care. 2021;11:9. https:// doi.org/10.1186/s13613-020-00798-X.

\section{Publisher's Note}

Springer Nature remains neutral with regard to jurisdictional claims in published maps and institutional affiliations.

The original article can be found online at https://doi.org/10.1186/s13613020-00798-x

*Correspondence: hafd.aitoufella@aphp.fr

1 Service de Médecine Intensive-Réanimation, Hôpital Saint-Antoine,

Assistance Publique-Hôpitaux de Paris, 184 rue du faubourg

Saint-Antoine, 75571 Paris cedex 12, France

Full list of author information is available at the end of the article

SpringerOpen
(0) The Author(s) 2021. This article is licensed under a Creative Commons Attribution 4.0 International License, which permits use, sharing, adaptation, distribution and reproduction in any medium or format, as long as you give appropriate credit to the original author(s) and the source, provide a link to the Creative Commons licence, and indicate if changes were made. The images or other third party material in this article are included in the article's Creative Commons licence, unless indicated otherwise in a credit line to the material. If material is not included in the article's Creative Commons licence and your intended use is not permitted by statutory regulation or exceeds the permitted use, you will need to obtain permission directly from the copyright holder. To view a copy of this licence, visit http://creativecommons.org/licenses/by/4.0/ 